\title{
Evaluasi Produktivitas Bongkar Muat Petikemas pada PT. Berlian Jasa Terminal Indonesia (BJTI Port) di Tanjung Perak-Surabaya
}

\author{
Evaluation of Productivity Unloading Container at PT. Diamond Service \\ Terminal Indonesia (BJTI Port) in Tanjung Perak-Surabaya \\ Reny Rochmawati ${ }^{1 *}$, Ari Widayanti ${ }^{2}$ \\ ${ }^{1,2}$ Program Studi Transportasi, Program Vokasi, Universitas Negeri Surabaya
}

\begin{tabular}{l}
\hline ARTICLE INFO \\
\hline Article history: \\
DOI: \\
10.30595/pspfs.v1i.150 \\
Submitted: \\
June 28, 2021 \\
Accepted: \\
July 10, 2021 \\
Published: \\
Oct 31, 2021 \\
\hline
\end{tabular}

Keywords:

Loading and Unloading, Containers, Productivity, Time Series

\begin{abstract}
Evaluation of loading and unloading productivity is an important thing that must be done because it minimizes the occurrence of obstacles in loading and unloading and helps determine the right steps to increase productivity in the following year. The purpose of this study is to determine the factors that affect the productivity of loading and unloading, calculate the percentage of productivity and determine the forecasting value of loading and unloading productivity for the next 10 years. This is expected to improve services with technological innovation and the development of related science. The method used was the time series method. The results were obtained from PT. BJTI in 2017 - 2020, the obstacles that occurred tended to decrease, so the percentage of productivity increased every year. Based on the forecasting results with the time series method, loading and unloading productivity in $2021-2030$ showed a significant increase. In 2030 the total productivity of loading and unloading was obtained at 1,397,463 boxes. This showed that the total loading and unloading in 2030 did not affect the equipment's ability in the loading and unloading process because the equipment capacity was still sufficient to accommodate up to 2,242,560 boxes per year. Therefore, it was not necessary to add more HMC tools at Berlian Terminal. This was inversely proportional to the loading and unloading stack obstacles whose solution must be to add RTG heavy equipment so that the loading and unloading process would be faster.
\end{abstract}

This work is licensed under a Creative Commons Attribution 4.0 International License.

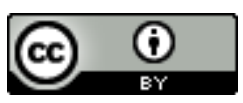

\author{
Corresponding Author: \\ Reny Rochmawati \\ Program Studi Transportasi, Program Vokasi, Universitas Negeri Surabaya, Kampus Unesa \\ Jalan Ketintang, Surabaya \\ Email: reny.18014@mhs.unesa.ac.id
}

\section{PENDAHULUAN}

Bongkar muat adalah kegiatan bongkar muat barang dari atas kapal atau ke kapal meliputi kegiatan pembongkaran barang dari palka kapal, ke atas dermaga, di lambung kapal atau sebaliknya (stevedoring), kegiatan pemindahan barang dari dermaga di lambung kapal ke gudang penumpukan atau sebaliknya (cargodoring) dan kegiatan pengambilan barang dari gudang/lapangan dibawa keatas truk atau sebaliknya (receiving/delivery) atau sebaliknya (Kemenhub, 2001). Bongkar muat pada pelabuhan merupakan satu kegiatan usaha jasa yang penting sebagai penunjang kegiatan angkutan laut, sehingga dapat meningkatkan pelayanan dengan inovasi teknologi dan pengembangan ilmu pengetahuan terkait.

PT. Berlian Jasa Terminal Indonesia merupakan salah satu perusahaan penyedia jasa bongkar muat yang terpercaya di Indonesia, karena mempunyai area operasional yang luas dan jaringan terpadu di seluruh Indonesia. PT. Berlian Jasa Terminal Indonesia merupakan anak perusahaan dari PT. Pelabuhan Indonesia III (Persero) yang bertugas untuk menangani jasa kepelabuhan termasuk didalamnya kegiatan bongkar muat petikemas domestik di Terminal 
Berlian Tanjung Perak Surabaya. PT. Berlian Jasa Terminal Indonesia juga mengatur kegiatan pelayanan gudang konsolidasi impor dan jasa plug untuk reefer container.

Bongkar Muat dalam pelaksanaannya didapatkan faktor penghambat. Berdasarkan faktor penghambat inilah yang menjadikan produktivitas dalam bongkar muat tidak selalu stabil dalam setiap bulan. Banyak faktor yang berpengaruh terhadap kecepatan bongkar muat baik dari luar atau dari dalam. Dalam memastikan secara spesifik hal yang mempengaruhi produktivitas bongkar muat, maka diperlukan analisis kemudian dilanjutkan ke tahap evaluasi. Setelah itu, meramalkan nilai produktivitas untuk tahun berikutnya. Hal ini untuk menentukan langkah yang terbaik untuk meminimalisir hambatan dan meningkatkan produktivitas tersebut. Oleh sebab itu, penulis ingin mengulasnya melalui makalah yang berjudul "Evaluasi Produktivitas Bongkar Muat Petikemas Pada PT. Berlian Jasa Terminal Indonesia (BJTI PORT) di Tanjung Perak, Surabaya". Tujuan dari penelitian ini adalah untuk mengetahui faktor yang berpengaruh terhadap produktivitas bongkar muat, menghitung persentase produktivitas dan mengetahui nilai peramalan produktivitas bongkar muat untuk 10 tahun kedepan dari tahun $2021-2030$.

\section{METODE PENELITIAN}

Tahapan dalam penelitian ini meliputi pengumpulan data primer dan sekunder, analisis data. Berdasarkan analisis data dilakukan pengujian untuk memperoleh hasil akhir, sehingga dapat ditentukan simpulan dan sarannya. Metode yang digunakan adalah metode peramalan time series (Analisis pola hubungan antara variabel yang diperkirakan dengan dengan variabel waktu). Berikut persamaan liniernya:

$$
\begin{gathered}
\hat{Y}=a+b X \\
a=\frac{E Y}{m p} \\
b=\frac{\Sigma X Y}{\Sigma X^{2}}
\end{gathered}
$$

Keterangan:

$$
\begin{aligned}
& \hat{\mathrm{Y}}=\text { Nilai ramalan } \quad \mathrm{X}=\text { Nilai Periode } \\
& \mathrm{a}=\text { Nilai konstanta } \mathrm{n}=\text { Banyaknya Data }
\end{aligned}
$$

$\mathrm{b}=$ Nilai kemiringan

Penelitian ini juga mengukur ketepatan metode ramalan tersebut untuk menentukan hasil yang paling baik menurut Suharyadi \& Purwanto yang dikutip oleh (Tutut, 2017). Ukuran kesalahan yang digunakan dalam penelitian ini adalah:

$$
\begin{aligned}
\text { MAE } & =\frac{\Sigma[Y-\hat{Y} \mid}{n} \\
\text { MSE } & =\frac{\Sigma(Y-\hat{Y})^{2}}{n} \\
\text { MAPE } & =\frac{\Sigma(Y-\hat{Y}) / Y}{n}
\end{aligned}
$$

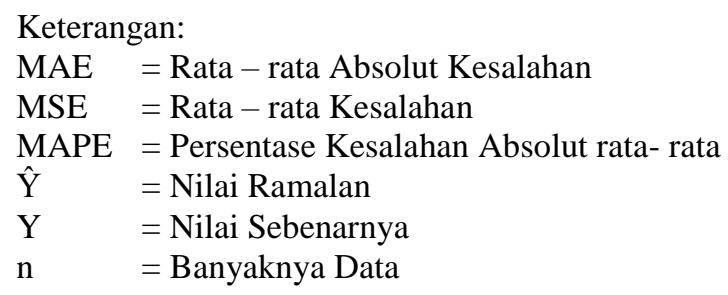

Intepretasi nilai MAPE dikategorikan menjadi 4 menurut Lewis yang dikutip oleh (Rizki dkk, 2011) yaitu:

Tabel 1. Intepretasi nilai MAPE

\begin{tabular}{cl}
\hline Banyak Interval & \multicolumn{1}{c}{ MAPE ( \% ) } \\
\hline$<10$ & Peramalan Sangat Akurat \\
$10-20$ & Peramalan Baik \\
$20-50$ & Peramalan Layak \\
$>50$ & Peramalan Kurang Akurat
\end{tabular}

Dari 4 kategori tersebut nantinya dapat disimpulkan keakuratan dari data yang telah di analisis. 


\section{HASIL DAN PEMBAHASAN}

\section{Faktor hambatan bongkar muat}

Berdasarkan hasil analisis diperoleh bahwa faktor hambatan dalam bongkar muat yaitu:

1. Hambatan dari Dalam (Internal)

Hambatan yang berasal dari dalam lingkup Terminal Berlian, yang meliputi:

a) Idle CY ramai

Hambatan berupa kemacetan didalam CY Berlian. karena kurang luasnya CY disertai dengan banyaknya armada yang menunggu antrian untuk mengambil bongkaran, proses muatan dan menunggu antrian stack.

b) Idle Haulage

Hambatan terjadi karena kurangnya armada BJTI (haulage). karena banyak haulage dalam proses perbaikan dan kurangnya armada pelayaran dalam proses pengambilan bongkaran, sehingga terjadi antrian.

c) Idle Alat Trouble

Hambatan yang terjadi karena kerusakan alat baik HMC maupun RTG. Kerusakan ini mengakibatkan waktu untuk bongkar muat terhenti cukup lama karena harus menunggu alat diperbaiki

d) Idle Spreader Trouble

Hambatan yang terjadi pada spreader alat HMC atau RTG. Hal ini lebih sering terjadi pada spreader HMC karena pergerakan spreader pada alat tersebut lebih jauh dibandingkan RTG.

e) Idle Shifting Alat

Hambatan ini terjadi karena 3 faktor, yaitu:

a) Kerusakan alat baik HMC yang proses perbaikannya menunggu lama

b) Idle shifting alat yang terjadi karena perpindahan alat RTG dari blok ke blok berikutnya.

c) Pergeseran alat mengikuti posisi container dalam kapal.

f) Idle Cuaca Buruk

Hambatan yang terjadi karena cuaca ekstrim yang dapat mengganggu alat HMC dan RTG

Tabel 2. Waktu hambatan berdasarkan I-Port

\begin{tabular}{|c|c|c|c|c|c|}
\hline \multirow[b]{2}{*}{ No } & \multirow{2}{*}{$\begin{array}{c}\text { Faktor } \\
\text { Hambatan dari } \\
\text { Dalam }\end{array}$} & \multicolumn{4}{|c|}{ Tahun } \\
\hline & & 2017 & 2018 & 2019 & 2020 \\
\hline 1 & Idle CY Ramai & 947,82 & 675,16 & 163,22 & 44,31 \\
\hline 2 & Idle Haulage & 261,22 & 111,44 & 5,91 & 0,00 \\
\hline 3 & $\begin{array}{l}\text { Idle Alat } \\
\text { Trouble }\end{array}$ & 448,72 & 133,52 & 404,28 & 383,82 \\
\hline 4 & $\begin{array}{c}\text { Idle Spreader } \\
\text { Trouble }\end{array}$ & 838,72 & 322,33 & 40,43 & 0,00 \\
\hline 5 & $\begin{array}{c}\text { Idle Shifting } \\
\text { Alat }\end{array}$ & 1475,80 & 312,2 & 8,93 & 4,77 \\
\hline 6 & $\begin{array}{c}\text { Idle Cuaca } \\
\text { Buruk }\end{array}$ & 88,64 & 32,93 & 25,44 & 6,34 \\
\hline
\end{tabular}

Berdasarkan Tabel 2 diperoleh pada tahun 2017 idle tertinggi pada shifting alat. Hal ini terjadi karena bagian mekanik masih terbatas, sehingga proses perbaikan butuh waktu lama dan terjadi shifting alat. Idle paling rendah adalah cuaca buruk karena bongkar muat dihentikan ketika angin melebihi 8 knot. Pada tahun 2018, hambatan tertinggi pada idle haulage. Hal ini terjadi karena haulage banyak perbaikan sedangkan banyak armada yang terlambat dalam pengambilan container, sehingga haulage tidak mencukupi untuk menggantikan. Pada tahun 2019, hambatan tertinggi pada idle alat trouble karena banyak alat yang rusak dan butuh waktu perbaikan yang lama. Oleh sebab itu, shifting alat merupakan idle paling rendah ditahun tersebut. Pada tahun 2020, hambatan tertinggi pada idle alat trouble nilainya sama dengan yang terjadi pada tahun 2019 karena terjadi banyak kerusakan alat. Idle paling rendah yang terjadi adalah idle haulage dan spreader trouble. Kedua idle ini bernilai 0 kemungkinan pada saat input terjadi kendala pada sistem. Berdasarkan data tersebut, dapat disimpulkan bahwa hambatan tertinggi terjadi pada tahun 2017 pada idle CY ramai dan hambatan terendah pada tahun 2020 yaitu idle haulage dan spreader troubl.

2. Hambatan dari Luar (Eksternal)

Hambatan yang berasal dari luar lingkup Terminal Berlian, yang meliputi :

a) Idle Tunggu Muatan depo

Hambatan yang terjadi karena menunggu armada pelayaran yang mengangkut container untuk dimuat. Hal ini karena 3 faktor yaitu : 
- Terjadi keterlambatan karena armada mengalami kemacetan di jalan

- Terjadi kendala saat di depo pelayaran.

- Tidak dapat masuk gate in karena status container belum di coparn

b) Idle Tunggu Armada TL (Truck Lossing)

Hambatan ini terjadi karena 2 faktor, yaitu :

- Terjadi kekurangan armada pelayaran dalam proses pengambilan bongkaran.

- Armada pelayaran terjebak macet, sehingga mengalami keterlambatan bongkaran di Terminal.

Tabel 3. Waktu hambatan berdasarkan I-Port

\begin{tabular}{cccccc}
\hline \multirow{2}{*}{ No. } & Faktor Hambatan Luar & $\mathbf{2 0 1 7}$ & $\mathbf{2 0 1 8}$ & $\mathbf{2 0 1 9}$ & $\mathbf{2 0 2 0}$ \\
\hline 1 & Idle Tunggu Muatan Depo & 3799,48 & 1070,17 & 163,22 & 44,31 \\
2 & Idle Tunggu Armada TL (Truck Lossing) & 1079,26 & 333,08 & 33,11 & 8,93 \\
\hline
\end{tabular}

Berdasarkan Tabel 3 diperoleh pada tahun 2017 - 2020 hambatan tertinggi pada idle tunggu muatan depo. Karena banyak kendala dari luar seperti kemacetan, container belum coparn saat di gate in, container melebihi kapasitas maximum, selain itu banyak faktor lain dari pihak pelayaran itu sendiri. Selain itu, hambatan paling rendah terjadi pada idle tunggu armada TL. Hal ini terjadi karena 2 faktor yaitu banyak armada TL yang terlambat dalam mengambil bongkaran atau kekurangan armada dalam mengambil container di terminal.

\section{a. Perhitungan Persentase Produkivitas Bongkar Muat}

Sebelum menghitung persentase produktivitas, harus menghitung nilai BSH untuk mengetahui jumlah box container yang dibongkar/dimuat kapal dalam waktu 1 jam. Setelah mengetahui nilai BSH, dilanjutkan perhitungan persentase produktivitas bongkar muat. Berikut hasil perhitungan produktivitas dalam kurun waktu 4 tahun :

1. Persentase Produktivitas Pada Tahun 2017-2020

Berdasarkan hasil penelitian, didapatkan data untuk menghitung nilai BSH seperti pada tabel berikut :

Tabel 4. Nilai BSH pada tahun 2017-2018

\begin{tabular}{cccccc}
\hline No & Bulan & $\mathbf{2 0 1 7}$ & $\mathbf{2 0 1 8}$ & $\mathbf{2 0 1 9}$ & $\mathbf{2 0 2 0}$ \\
\hline 1 & Januari & 11,98 & 14,36 & 25,24 & 24,07 \\
2 & Februari & 11,74 & 14,66 & 22,00 & 24,52 \\
3 & Maret & 12,23 & 14,36 & 21,97 & 25,12 \\
4 & April & 13,21 & 17,38 & 21,69 & 24,91 \\
5 & Mei & 14,38 & 17,71 & 21,44 & 20,11 \\
6 & Juni & 13,15 & 18,36 & 22,25 & 20,25 \\
7 & Juli & 13,43 & 20,52 & 23,46 & 20,69 \\
8 & Agustus & 14,32 & 21,91 & 22,59 & 19,72 \\
9 & September & 13,65 & 24,03 & 24,51 & 20,37 \\
10 & Oktober & 14,00 & 25,24 & 25,20 & 20,29 \\
11 & November & 12,93 & 25,59 & 24,74 & 18,04 \\
12 & Desember & 13,24 & 24,94 & 23,32 & 16,33 \\
\hline
\end{tabular}

Berdasarkan Tabel 4 diketahui nilai BSH tertinggi pada tahun 2017 terjadi pada bulan Mei dengan nilai 14,38 box/jam. Nilai BSH terendah terjadi pada bulan Februari dengan nilai 11,74 box/jam. Kedua nilai ini masih sangat kecil, karena standar nilai BSH yang ditetapkan pada PT. BJTI adalah 30 box/jam. Nilai BSH pada tahun 2017 kecil dikarenakan idle time yang cukup tinggi, selain itu keahlian operator masih kurang sehingga kecepatan dalam mengoperasikan alat cenderung lebih lama.

Nilai BSH tertinggi pada tahun 2018 terjadi pada bulan November dengan nilai 25,59 box/jam. Nilai BSH terendah terjadi pada bulan Januari dan Maret dengan nilai 14,36 box/jam. Pada tahun 2018 peningkatan BSH cukup signifikan, karena nilai tertinggi hampir mendekati target BSH yang di harapkan oleh PT. BJTI yakni 30 box/jam. Hal ini terjadi dikarenakan peningkatan keahlian operator, sehingga pengoperasian alat lebih cepat.

Nilai BSH tertinggi pada tahun 2019 terjadi pada bulan Januari dengan nilai 25,24 box/jam. Nilai BSH terendah terjadi pada bulan Mei dengan nilai 21,44 box/jam. Pada tahun 2019 nilai BSH cukup stabil karena selama 12 bulan berada pada nilai 20 - 25 box/jam, walaupun target BSH belum memenuhi target tetapi sudah cukup baik. Hal ini 
terjadi dikarenakan operator selalu memeperbaiki kualitasnya dalam pengoperasian alat.

Nilai BSH tertinggi pada tahun 2020 terjadi pada bulan Maret dengan nilai 25,12 box/jam. Nilai BSH terendah terjadi pada bulan Desember dengan nilai 21,44 box/jam. Pada tahun 2020 nilai BSH dari bulan April - Desember mengalami penurunan dikarenakan adanya pandemi covid-19. Adanya pandemi ini mengakibatkan banyak operator yang harus isolasi mandiri dan digantikan dengan operator baru yang keahliannya masih kurang dalam pengoperasian alat. Setelah didapatkan nilai BSH dari setiap tahum, maka dapat diperoleh hasil grafik persentase produktivitas sebagai berikut:

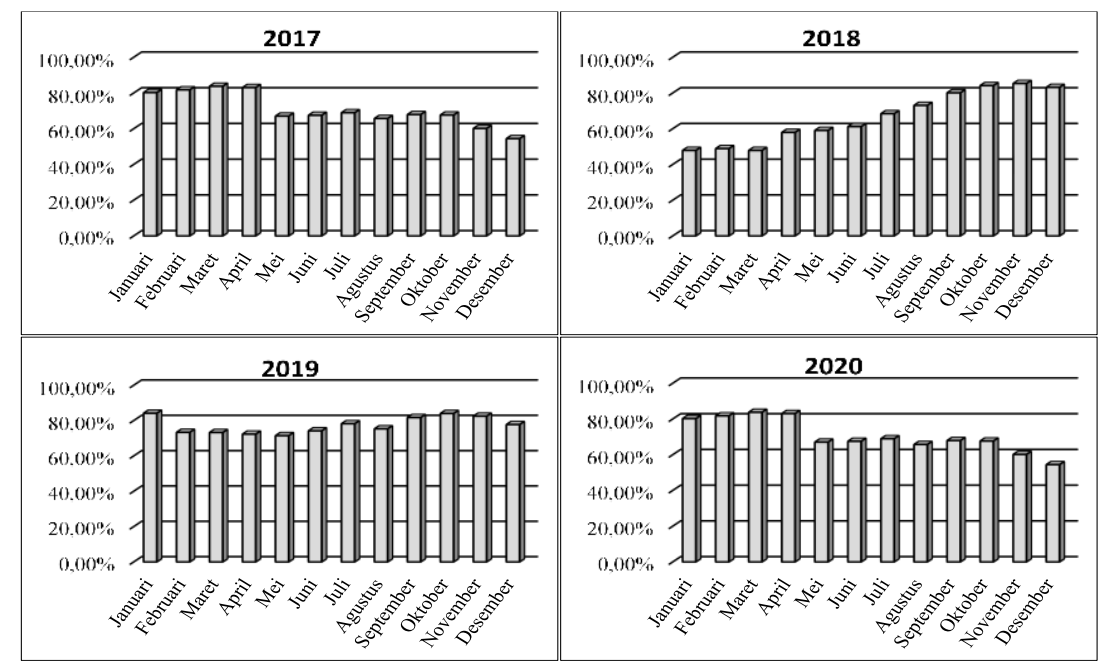

Gambar 1. Persentase Produktivitas Bongkar Muat dari tahun 2017-2020

Berdasarkan Gambar 1 diketahui bahwa :

1. Tahun 2017 persentase produktivitas mengalami naik turun. Persentase tertinggi pada bulan Mei dengan nilai 47,92\%. Karena jumlah gang banyak dan hambatan cukup rendah. Oleh sebab itu, BSH bernilai cukup tinggi dibandingkan bulan yang lain. Presentase produktivitas terendah pada bulan Februari dengan nilai 39,15\%. Terjadi karena jumlah gang sedikit dan banyak hambatan dalam bongkar muat, sehingga BSH tersebut bernilai kecil.

2. Tahun 2018 persentase produktivitas mengalami peningkatan dari tahun sebelumnya. persentase tertinggi pada bulan November dengan nilai $85,31 \%$. Karena jumlah gang lebih banyak, hambatan pada bulan November cukup rendah dan kecepatan operator mengoprasikan alat cukup cepat. Oleh sebab itu, BSH bernilai cukup tinggi dibandingkan bulan yang lain. Persentase produktivitas terendah pada bulan Januari dan Maret dengan nilai $47,85 \%$. Karena gang yang digunakan sedikit dan banyak terjadi hambatan data proses bongkar muat, sehingga nilai BSH pada bulan tersebut bernilai kecil.

3. Tahun 2019 persentase produktivitas stabil tidak mengalami kenaikan dan penurunan yang drastis. Dalam 12 bulan persentase tertinggi pada bulan Januari dengan nilai $84,14 \%$. Karena jumlah gang lebih banyak, dan kecepatan operator mengoperasikan alat HMC. Oleh sebab itu, BSH bernilai tinggi dibandingkan bulan lain. Persentase produktivitas terendah terjadi bulan Mei dengan nilai 71,25\%. Parena kecepatan operator alat, walaupun jumlah gang digunakan banyak dan hambatan yang terjadi tidak tinggi. Hal ini berakibat nilai BSH bernilai kecil.

4. Tahun 2020 persentase produktivitas tidak stabil mengalami penurunan yang drastis. Dalam 12 bulan perasentase tertinggi pada bulan Maret dengan nilai 83,74\%. Hal ini terjadi karena gang lebih banyak, dan kecepatan operator mengoperasikan alat HMC walaupun hambatan yang terjadi cukup tinggi. Oleh sebab itu, BSH bernilai cukup tinggi dibandingkan bulan yang lain. Persentase produktivitas terendah terjadi pada bulan Desember dengan nilai $54,44 \%$. Hal ini terjadi karena jumlah gang lebih sedikit dibanding bulan sebelumnya dan hambatan yang terjadi cukup banyak. Selain itu, banyak karyawan dari PT. BJTI yang harus isolasi mandiri karena covid-19. Hal ini dapat mempengaruhi tingkat produktivitas bongkar muat sehingga nilai BSH pada bulan tersebut bernilai kecil.

\section{b. Peramalan dengan Time Series}

Berdasarkan data sekunder dari PT. BJTI diperoleh data selama 4 tahun dari tahun 2017 - 2020 yang menunjukkan jumlah kapal dan jumlah bongkar muat pertahun. Data tersebut dapat dilihat pada tabel : 
Tabel 5. Jumlah kapal dan Bongkar Muat pertahun

\begin{tabular}{ccc}
\hline Tahun & Jumlah Kapal & Total Bongkar Muat \\
\hline 2017 & 2.755 & 984.919 \\
2018 & 2.776 & 1.092 .819 \\
2019 & 2.701 & 1.111 .478 \\
2020 & 2.970 & 1.129 .969 \\
Total & $\mathbf{1 1 . 2 0 2}$ & $\mathbf{4 . 3 1 9 . 1 8 5}$ \\
\hline
\end{tabular}

Berdasarkan Tabel 5 diketahui jumlah kapal pada tahun 2019 cenderung mengalami penurunan, dikarenakan kapal yang sandar pada tahun 2019 mayoritas adalah kapal besar yang bermuatan banyak. Oleh karena itu, walaupun jumlah kapal lebih sedikit dibanding 2018 tetapi total bongkar muat lebih banyak di tahun 2019. Pada tahun 20172020 jumlah container yang dibongkar muat selalu mengalami peningkatan setiap tahunnya karena jumlah permintaan barang semakin banyak. Setelah mengetahui jumlah kapal dan jumlah bongkar muat, dilanjutkan ke metode prediksi. Berikut hasil yang diperoleh dengan metode prediksi:

Tabel 6. Jumlah Kapal dan Bongkar Muat dengan metode Time Series

\begin{tabular}{ccccccccc}
\hline Tahun & $\begin{array}{c}\text { Jumlah Kapal } \\
(\mathbf{Y})\end{array}$ & $\mathbf{X}$ & $\mathbf{X}^{\mathbf{2}}$ & $\mathbf{X Y}$ & $\begin{array}{c}\text { Total } \\
\text { Bongkar Muat } \\
(\mathbf{Y})\end{array}$ & $\mathbf{X}$ & $\mathbf{X}^{\mathbf{2}}$ & $\mathbf{X Y}$ \\
\hline 2017 & 2.755 & -3 & 9 & - & 984.919 & -3 & 9 & -2.954 .757 \\
& & & & 8265 & & & & \\
2018 & 2.776 & -1 & 1 & - & 1.092 .819 & -1 & 1 & -1.092 .819 \\
2019 & 2.701 & 1 & 1 & 2776 & 1.111 .478 & 1 & 1 & 1.111 .478 \\
2020 & 2.970 & 3 & 9 & 8910 & 1.129 .969 & 3 & 9 & 3.389 .907 \\
Total & $\mathbf{1 1 2 0 2}$ & $\mathbf{0}$ & $\mathbf{2 0}$ & $\mathbf{5 7 0}$ & $\mathbf{4 . 3 1 9 . 1 8 5}$ & $\mathbf{0}$ & $\mathbf{2 0}$ & $\mathbf{4 5 3 . 8 0 9}$ \\
\hline
\end{tabular}

Berdasarkan Tabel 6 diperoleh hasil prediksi yang digunakan dalam perhitungan peramalan jumlah kapal pada 10 tahun kedepan. Nilai x didapatkan dari aturan perhitungan time series, bahwa data genap skor nilai x nya yaitu ..., $-5,-3,-1,1,3,5, \ldots$. Begitu juga dengan perhitungan peramalan jumlah bongkar muat pada 10 tahun kedepan. Data yang diperoleh merupakan data genap, maka skor nilai x nya sama seperti prediksi jumlah kapal. Setelah didapatkan nilai variabel $\mathrm{X}, \mathrm{X}^{2}, \mathrm{XY}$, sesuai dengan metode Time Series maka selanjutnya dilakukan proses perhitungan dengan menggunakan metode yang sudah dijelaskan.

$$
\begin{aligned}
& \text { Produktivitas Kapal } \\
& \begin{array}{ll}
a=\frac{\Sigma Y}{n}=\frac{11202}{4} & =2.795,5 \\
b=\frac{\sum X Y}{\Sigma X^{2}}=\frac{570}{20} & =28,5
\end{array}
\end{aligned}
$$

Persamaan untuk metode kuadrat terkecil sebagai berikut :

$$
\begin{aligned}
\hat{\mathrm{Y}} & =\mathrm{a}+\mathrm{bx} \\
& =2795,5+(28,5 \times(4)) \\
& =2.943
\end{aligned}
$$

\section{Produktivitas Bongkar Muat}

$$
\begin{array}{lll}
a=\frac{\sum Y}{n} & =\frac{4319185}{4} & =1.079 .796 \\
b=\frac{\sum X Y}{\sum X^{2}} & =\frac{453809}{20} & =22.690,25
\end{array}
$$

Persamaan untuk metode kuadrat terkecil sebagai berikut :

$$
\begin{aligned}
\hat{\mathrm{Y}} \quad & =\mathrm{a}+\mathrm{bx} \\
& =1079796+(22690,25 \times(4)) \\
& =1.193 .249
\end{aligned}
$$


Setelah ditemukan hasil prediksi tahun berikutnya, maka selanjutnya dihitung prediksi sampai tahun 2030, menggunakan metode yang sama. Didapatkan hasil sebagai berikut :
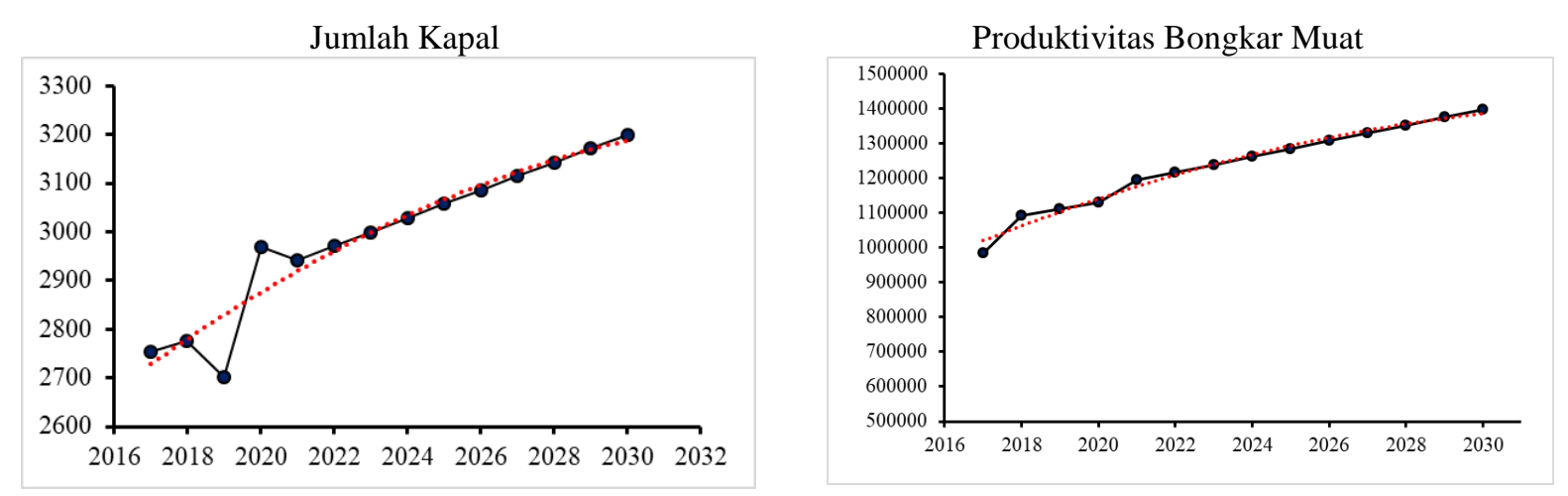

Gambar 2. Hasil Prediksi Jumlah Kapal dan Total Bongkar Muat sampai Tahun 2030

Berdasarkan gambar 2 pada prediksi jumlah kapal dapat diketahui bahwa terjadi penurunan yang drastis dari tahun 2018 ke 2019. Hal ini terjadi karena pada tahun 2019 kapal yang bongkar muat di Terminal Berlian mayoritas merupakan kapal besar yang dapat mengangkut container dalam jumlah banyak. Pada tahun 2020, terjadi kenaikan yang cukup signifikan karena kapal yang bongkar muat di terminal Berlian mayoritas adalah kapal kecil, sehingga jumlah kapal cukup banyak. Berdasarkan hasil prediksi pada tahun 2021 - 2030 kapal selalu mengalami peningkatan dan prediksi total bongkar muat juga terus mengalami peningkatan setiap tahunnya. Hal ini terjadi karena kebutuhan masyarakat dalam mengirim barang semakin bertambah disetiap tahunnya.

Setelah ditemukan hasil dari prediksi jumlah kapal sampai tahun 2030, maka selanjutnya dilakukan pengukuran ketepatan peramalan. Berikut hasil nilai yang digunakan untuk perhitungan ketepatan peramalan jumlah kapal:

Tabel 7. Pengukuran Peramalan Jumlah Kapal

\begin{tabular}{ccccccc}
\hline Tahun & $\begin{array}{c}\text { Jumlah } \\
\text { Kapal ( Y ) }\end{array}$ & $\begin{array}{c}\text { Ramalan } \\
\mathbf{y}\end{array}$ & $\begin{array}{c}\text { Kesalahan } \\
(\mathbf{e})\end{array}$ & $\sum \boldsymbol{Y}-\breve{\mathbf{y}}$ & $\sum \boldsymbol{Y}-\breve{\mathbf{y}} \mathbf{2}$ & $\sum(\mathbf{Y}-\breve{\mathbf{y}}) / \mathbf{Y}$ \\
\hline 2017 & 2.755 & - & - & - & - & - \\
2018 & 2.776 & 2.755 & 21 & 21 & 441 & 0,00756 \\
2019 & 2.701 & 2.776 & -75 & 75 & 5625 & 0,02777 \\
2020 & 2.970 & 2.701 & 269 & 269 & 72.361 & 0,09057 \\
Total & $\mathbf{1 1 2 0 2}$ & $\mathbf{8 . 2 3 2}$ & $\mathbf{2 1 5}$ & $\mathbf{3 6 5}$ & $\mathbf{7 8 . 4 2 7}$ & $\mathbf{0 , 1 2 5 9}$ \\
\hline
\end{tabular}

Berdasarkan Tabel 7 dapat diketahui nilai - nilai untuk perhitungan dalam ketepatan peramalan jumlah kapal, nilai tersebut digunakan untuk menghitung MAE, MSE, dan MAPE.

$$
\begin{array}{rlrl}
\text { MAE } & =\frac{\Sigma|Y-\hat{Y}|}{n}=\frac{365}{4} & =91,25 \\
\text { MSE }=\frac{\Sigma(Y-\hat{Y})^{2}}{n}=\frac{78427}{4} & =19.606,75 \\
\text { MAPE }=\frac{\Sigma(Y-\hat{Y}) / Y}{n}=\frac{0,12590}{4} & =0,031475
\end{array}
$$

Berdasarkan hasil perhitungan MAPE, diperoleh nilai 0,031475 atau 3,1\%. Hal ini dapat diinterpretasikan bahwa peramalan jumlah kapal menunjukkan sangat akurat karena masuk kedalam interval $<10 \%$. Sedangkan untuk produktivitas Bongkar Muat, adalah sebagai berikut : 
Tabel 8. Pengukuran Peramalan Produktivitas Bongkar Muat

\begin{tabular}{ccccccc} 
Tahun & $\begin{array}{c}\text { Jumlah } \\
\text { BM }(\mathbf{Y})\end{array}$ & Ramalan $\check{\mathbf{y}}$ & $\begin{array}{c}\text { Kesalahan } \\
(\mathbf{e})\end{array}$ & $\sum \boldsymbol{Y}-\breve{\mathbf{y}}$ & $\sum \boldsymbol{Y}-\check{\mathbf{y}} \mathbf{2}$ & $\sum(\mathbf{Y}-\check{\mathbf{y}}) / \mathbf{Y}$ \\
\hline 2017 & 984.919 & - & - & - & - & - \\
2018 & 1.092 .819 & 984.919 & 107.900 & 107.900 & 11642410000 & 0,09873 \\
2019 & 1.111 .478 & 1.092 .819 & 18.659 & 18.659 & 348158281 & 0,01678 \\
2020 & 1.129 .969 & 1.111 .478 & 18.491 & 18.491 & 341917081 & 0,01636 \\
Total & $\mathbf{4 . 3 1 9 . 1 8 5}$ & $\mathbf{3 . 1 8 9 . 2 1 6}$ & $\mathbf{1 4 5 . 0 5 0}$ & $\mathbf{1 4 5 . 0 5 0}$ & $\mathbf{1 2 . 3 3 2 . 4 8 5 . 3 6 2}$ & $\mathbf{0 , 1 3 1 8 7}$ \\
\hline
\end{tabular}

Berdasarkan pada Tabel 8 dapat diketahui nilai - nilai untuk pengukuran dalam ketepatan peramalan jumlah bongkar muat, nilai tersebut digunakan untuk menghitung MAE, MSE, dan MAPE.

$$
\begin{array}{ccc}
\text { MAE }=\frac{\Sigma|Y-\hat{Y}|}{\mathrm{n}} & =\frac{145050}{4} & =36.262,5 \\
\text { MSE }=\frac{\Sigma(Y-\hat{Y})^{2}}{\mathrm{n}}=\frac{12332485362}{4} & =3.083 .121 .340,5 \\
\text { MAPE }=\frac{\Sigma(Y-\hat{Y}) / Y}{\mathrm{n}}=\frac{0,13187}{4} & =0,0329675
\end{array}
$$

Berdasarkan hasil perhitungan MAPE, diperoleh nilai 0,0329675 atau 3,2\%. Hal ini dapat diinterpretasikan bahwa peramalan jumlah bongkar muat menunjukkan sangat akurat karena masuk kedalam interval $<10 \%$.

Berdasarkan hasil peramalan, jumlah bongkar muat di Terminal Berlian mengalami kenaikan setiap tahunnya. Hal ini terjadi karena jumlah permintaan konsumen semakin tinggi. Oleh karena itu diperlukan analisis perhitungan untuk mengetahui kesesuaian antara kebutuhan alat dan jumlah bongkar muat di Terminal Berlian. Berikut perhitungannya:

- Kapasitas crane $\quad=16$ Box/jam (Standar)

- Waktu kerja/tahun = 365 hari

- Sheet yang tersedia $=3$ sheet

$=24 \mathrm{jam}$

Waktu tersedia $\quad=365 \times 24$ jam

$=8.760 \mathrm{jam} / \mathrm{tahun}$

- Kapasitas Alat $\quad=16$ Box x 8760 jam

$=140.160$ Box/tahun

- Alat ( 16 ) Unit $=16 \times 140160$

$=2.242 .560$ Box

Tabel 9. Hasil Peramalan

\begin{tabular}{|c|c|c|c|c|c|c|}
\hline No. & Tahun & Jumlah Kapal & Total & Bongkar Muat & Waktu Pertahun & Rata-rata Gang \\
\hline 1 & 2021 & 2.943 & & 1.193 .249 & 8.040 & 1,68 \\
\hline 2 & 2022 & 2.972 & & 1.215 .939 & 8.040 & 1,70 \\
\hline 3 & 2023 & 3.000 & & 1.238 .629 & 8.040 & 1,72 \\
\hline 4 & 2024 & 3.029 & & 1.261 .320 & 8.040 & 1,73 \\
\hline 5 & 2025 & 3.057 & & 1.284 .010 & 8.040 & 1,75 \\
\hline 6 & 2026 & 3.086 & & 1.306 .701 & 8.040 & 1,77 \\
\hline 7 & 2027 & 3.114 & & 1.329 .391 & 8.040 & 1,78 \\
\hline 8 & 2028 & 3.143 & & 1.352 .082 & 8.040 & 1,80 \\
\hline 9 & 2029 & 3171 & & 1.374 .772 & 8.040 & 1,81 \\
\hline 10 & 2030 & 3200 & & 1.397 .463 & 8.040 & 1,83 \\
\hline
\end{tabular}

Perhitungan kapasitas alat masih mencukupi untuk melayani bongkar muat sampai tahun 2030 dengan total bongkar muat sebesar 2242560 box. Hal ini menunjukkan bahwa pada PT. BJTI tidak perlu penambahan alat HMC untuk proses bongkar muat. Berdasarkan hasil peramalan jumlah bongkar muat di Terminal Berlian, dapat dilakukan analisis antara kebutuhan jumlah Gang dengan kondisi arus Berlian setiap tahunnya. diperoleh bahwa jumlah kebutuhan gang setiap tahunnya meningkat. Tetapi, peningkatan kebutuhan gang tidak terlalu signifikan apabila produktivitas bongkar muat di Terminal Berlian dimaksimalkan sesuai dengan standar kinerja pelabuhan. Upaya ini dilakukan untuk mencegah hal-hal yang bisa menyebabkan kerugian dipihak pelabuhan maupun dipihak pelayaran. 


\section{KESIMPULAN}

Berdasarkan hasil analisis data dan pembahasan, maka kesimpulan yang diperoleh sebagai berikut :

1. Berdasarkan perhitungan idle time, diperoleh bahwa faktor penghambat dari dalam yang paling mendominasi adalah Idle CY ramai. Hal ini dikarenakan CY Berlian yang kurang luas dan kurangnya alat RTG untuk setiap bloknya, sehingga sering terjadi perpindahan tempat stack yang mengakibatkan kemacetan di CY. Selain itu, faktor penghambat dari luar yang mendominasi adalah idle menunggu muatan Depo. Hal ini terjadi karena akses menuju Terminal Berlian seringkali mengalami kemacetan atau terjadi kendala saat container masuk ke gate in seperti belum coparn, berat lebihi batas maksimum, dan lain-lain.

2. Berdasarkan perhitungan persentase produktivitas dari tahun 2017 - 2020 diperoleh bahwa produktivitas selalu mengalami peningkatan. Tetapi, dalam waktu 4 tahun belum ada 1 bulan dimana produktivitas dapat memenuhi target $100 \%$. Hal ini dikarenakan target yang diberlakukan oleh Terminal Berlian cukup tinggi dibandingkan dengan standar yang diterapkan oleh operasional Pelindo III.

3. Berdasarkan perhitungan ramalan, diperoleh produktivitas bongkar muat dari tahun ke tahun selalu mengalami peningkatan. Tetapi, hasil analisis membuktikan bahwa untuk 10 tahun kedepan alat berat masih mencukupi. Hal ini berbanding terbalik dengan hambatan bongkar muat yang solusinya harus menambahkan alat berat agar proses dalam bongkar muat lebih cepat.

Saran yang dapat diberikan kepada PT. BJTI adalah :

1. Menambahkan alat RTG untuk setiap bloknya, agar mempermudah dan mempercepat dalam proses stack. Hal ini perlu dilakukan karena masih sering terjadi perpindahan alat RTG antar blok, sehingga mengganggu proses stack.

2. Lebih tegas dalam pemberian sanksi kepada perusahaan pelayaran yang belum coparn data container yang di stack/dimuat kapal. Tindakan ini perlu dilakukan karena banyak container dari pihak pelayaran yang belum dicoparn sehingga menyebabkan kemacetan di gate in. Oleh karena itu, sebaiknya diberikan tindakan yang tegas seperti pemberian denda untuk setiap container yang belum dicoparn.

3. Menambahkan alat berupa Automated Stacking Crane (ASC) seperti yang dimiliki oleh Terminal Multipurpose Teluk Lamong. Adanya penambahan alat berupa ASC dapat membuat keselamatan kerja lebih terjamin. Alat tersebut dapat berjalan secara otomatis karena crane dapat dikendalikan dari dalam ruang kontrol sehingga keselamatan operator mengoperasikan alat lebih terjamin karena tidak harus ke lapangan.

\section{UCAPAN TERIMAKASIH}

Penulis menyampaikan terima kasih yang mendalam kepada pihak PT. Berlian Jasa Terminal Indonesia (BJTI PORT) karena telah mengizinkan penulis untuk melakukan penelitian dan memperoleh data di instansi tersebut.

\section{DAFTAR PUSTAKA}

Putra, Yono. 2016. Evaluasi Pelayanan Penumpang Angkutan Laut di Terminal Gapura Surya Nusantara Pelabuhan Tanjung Perak - Surabaya. Tesis. Pascasarjana. Teknik Sipil. Universitas Atma Jaya, Yogyakarta.

Mabruroh, Aulya Rizqi Bani. 2016. Prosedur Pelaksanaan Receiving dan Delivery Petikemas di Terminal Serbaguna Nilam PT. Pelabuhan Indonesia III (Persero) Surabaya. Tugas Akhir. FISIP. Manajemen Administrasi. Universitas Sebelas Maret, Surakarta.

Indriastuti, Tutut. 2017. Analisis Time Series untuk Meramalkan Jumlah Penjualan pada Yamaha Mataram Sakti Kebumen dengan Metode Tren. Jurnal. Akuntansi. Akuntansi. Sekolah Ekonomi Putra Bangsa, Kebumen.

S. Hendra Gunawan, Suhartono, Analisis Faktoryang Berpengaruh terhadap Produktivitas Bongkar Muat Kontainer di Dermaga Berlian Surabaya (Studi Kasus PT. Pelayaran Meratus), Widya Tek., Vol. 7, no. 1, pp. 79-89, 2008.

M. Amrulloh Ibnu Kadun, Viqri Ilham Suryailahi, Pelaksanaan Bongkar Muat Peti dan Waktu Penyelesaian (Turn Round Time), J. Manaj. Bisnis Transp. dan Logsitik, Vol. 4, no. 3, pp. 297-302, 2018.

S. H. W. Rizki Agung Pambudi, Budi Darma Setiawan, Metode Time Series untuk Memprediksi Kemunculan Titik Api, J. Pengemb. Teknol. Inf. dan Ilmu Komput., Vol. 2, no. 11, pp. 4767-4776, 2018.

S. Luthfi Habibi Amanullah, M Gilang Indra Mardika, Slamet Hargono, Kajian Layanan dan Utilitas Dermaga Terminal Petikemas Pelabuhan Panjang, J. Karya Tek. Sipil, Vol. 7, no. 1, pp. 109-120, 2018. 